\title{
ERROR ANALYSIS OF VERB TENSE IN WRITING ESSAY TEXT
}

\author{
by \\ Akmalia Annisa ${ }^{1}$ (akmannis3011@gmail.com) \\ Shinta Fitri Laoly² (shintafitri1997@ gmail.com) \\ Claudia Atlanta Ulfa ${ }^{3}$ (claudiasebayang@gmail.com) \\ Yenni Silvia Br. Gurusinga ${ }^{4}$ (yennisilvia98@gmail.com) \\ Cindy Jessica ${ }^{5}$ (cindyjessica691@gmail.com) \\ Irma Khoirot Daulay, S.S., M.Hum. ${ }^{6}$ (irmakhoirotdaulay@ unprimdn.ac.id)
}

\begin{abstract}
The purpose of this study is to analyze students 'mistakes in essay writing especially in verbs and to understand the level of students ability to write English essays. This research method is qualitative descriptive. There were 15 students at SMK Mulia Pratama Vocational School that were used as research samples. In research that yielded: the level of student's ability to write English essays that require mistakes made on verbs is "fair.". The results of this level of ability are still somewhat lacking in the ability of students to write English by really prioritizing the use of verbs.
\end{abstract}

Key Words: error analysis, essay, verb tense

\section{A. INTRODUCTION}

As an international language, English lessons are very important to learn. Although it is still a difficult subject in Indonesian language schools, English lessons are highly prioritized. To communicate with people in the world, we use English as a unifying language. To speak well in English, one must be able to master a lot of vocabulary in speaking. Must be able to understand and respond well to reading and writing with correct grammatical patterns. Grammatical mistakes are the most common mistakes in conversation and writing in English. English language skills such as writing, reading, speaking and listening.

Writing is one of language skills, which generates ideas through written form. Knowing good and correct grammar patterns is something that must be done before writing. In addition, before writing we must be able to make a lot of vocabulary so that we can easily make word patterns in writing. Writing is an activity that is carried out in stages. As a creative process that occurs when writing 4 steps, namely: (1) preapproved, (2) search discovery (3) discovery discovery, and (4) development discovery.

The main purpose of writing is to be able to discuss various thoughts, opinions, and feelings in a variety of writings.Learning to write can start from activating or rewriting dictated text, writing through guidance or being controlled, until it finishes writing to communicate various messages.

An essay is a concise article that contains an opinion or an opinion that the author shows towards a particular topic. The essay is more on the discussion of the author's point of view on a topic or existing conflict. Essays are presented in written form which is systematic.

Verb tense is when the action occurs. The three main forms are: The Past Tense, The Present Tense, and The Future Tense. Verb tension can also tell us things like whether the action is habitual, ongoing, or finished. This is called the verb aspect, which is part of the tense. 
There are two previous researchers who have topics related to this research. First, Indrapasta's findings (2007: 71) find: the most common mistake is the subjectverb cooperation agreement and the score is $28,25 \%$. Second, place frequent errors on verbs and forms with $24,66 \%$ as a score. The third is spelling errors and is rated 17, $94 \%$. The score above is $9.9 \%$. Fifth is the word error sequence with a score of $8.07 \%$. The remaining errors were passive voice sentences with a score of $4.93 \%$, articles (3.59\%), prepositions (1.79\%), and pronouns and direct sentences with the same score, $0.45 \%$. Second, the results of Sawalmeh (2013: 1) show that Arabic speakers in this study made ten common mistakes. These errors are: (1) verbs, (2) word order, (3) singular / plural forms, (4) agreement-verbs, (5) double negatives, (6) spelling, (7) uppercase letters, (8) articles (9) sentence fragments and (10) prepositions. Can be understood in previous writers, verbs are mistakes that are still mostly made by students in writing essays. Therefore, in this article the author chose to study the errors of writing essays on verbs only with the aim of finding difficulties that asked students to write essays.

Based on the explanation in this background, the following questions are asked:

1. Why do errors in verbs often occur in writing English essays?

2. What difficulties did students face when writing essays especially the use of verbs?

In this study the authors see the results of errors made by students in the previous two articles are errors in verbs. Therefore, in this article the author chose to study the errors of writing essays on verbs with the aim of finding difficulties faced by students to write essays.

\section{a. Theoretical Frameworks}

Writing is an activity that gives birth to ideas and packages those ideas into various graphic forms that can help others (Nurhadi, 2019). In writing skills, grammar is a basic thing that must be learned before writing. Learning grammar in writing skills is not free because it is basic knowledge before writing. Understanding mastery level errors made in writing skills through the use of grammar rules in writing.

An essay is a short essay that contains opinions or opinions raised by the author of a particular topic discussion. According to Agus Widayoko (2019: 92). In a broader context, essays are one form of article. Essays are articles with specific characteristics and goals. The author tries to be easier than the article. In choosing essays, the writer only chooses important and interesting things from the written object or subject.

Khan and Khan (2016: 232-233) Correcting mistakes is the use of language items by means of fluent speakers or speakers According to Norrish in (Khan and Khan, 2016: 233) complicated difficulties as systematic deviations, complicated students have not learned anything and are fully complicated in getting their mistakes. However, in Khan and Khan (2016: 233), Cunning worth declared his mistake a systematic deviation from the norms of the language being translated.

Concerning grammatical errors, Shumaila Khan and Mohammed Riaz Khan (2016: 283) who analyzed errors in English written by Saudi students from Jazan University classified the following types of grammar: Verb Tense and Form, SubjectVerb Agreement, Word Order, Preposition, Articles, Tools, Spelling, Pronoun, Passive Sound, and Running Sentences.

\section{B. METHOD}

The writer in this research uses descriptive qualitative method. 
Miles, Huberman, and Saldana (2014) asked for qualitative research as a verification process. This kind of process is usually referred to as an inductive process. In addition to analyzing work errors in essay writing, researchers also find out the difficulties associated with essay writing.

Participants in this study were 15 students at the eleven class of SMK Mulia Pratama Medan, in English subjects. The data taken from this research is writing student essay writing.

The data of study were collected from student SMK Mulia Pratama. The students were wrote and essay about social media.

This study descriptive qualitative the data were analyzed by using the figure from Miles, Huberman, and Saldana (2014) namely: data collection, data condensation, data display and conclusion drawing / verifying.

Findings

Findings and Discussion

This study the authors get the results published by the table as follows:

\begin{tabular}{|cl|l|}
\hline Name & $\begin{array}{l}\text { Categori } \\
\text { es }\end{array}$ \\
\hline $\begin{array}{ll}\text { 1. } \\
\text { Giopani Br } \\
\text { Ginting }\end{array}$ & Fair \\
\hline 2. & Salwa & Poor \\
\hline 3. & Mozaid & Good \\
\hline 4. & $\begin{array}{l}\text { Elvina } \\
\text { Damayanti } \\
\text { Br } \\
\text { manulang }\end{array}$ & Fair \\
\hline 5. & $\begin{array}{l}\text { Amira } \\
\text { Sihombing }\end{array}$ & Poor \\
\hline 6. & $\begin{array}{l}\text { Elisabeth } \\
\text { Kaban }\end{array}$ & Fair \\
\hline 7. & Cori & Good \\
\hline 8. & $\begin{array}{l}\text { Hotmauli } \\
\text { Saragih }\end{array}$ & Fair \\
\hline 9. & $\begin{array}{l}\text { Gabriella } \\
\text { Veronika } \\
\text { sitorus }\end{array}$ & Fair \\
\hline
\end{tabular}

\begin{tabular}{|c|l|}
\hline $\begin{array}{c}\text { 10. Ainir } \\
\text { Hamnih }\end{array}$ & Good \\
\hline $\begin{array}{c}\text { 11. Anggi Ani } \\
\text { Sagita }\end{array}$ & Fair \\
\hline $\begin{array}{c}\text { 12. Yuliana } \\
\text { Tarigan }\end{array}$ & Poor \\
\hline 13. Samuel & $\begin{array}{l}\text { Very } \\
\text { good }\end{array}$ \\
\hline $\begin{array}{c}\text { 14. Franda } \\
\text { Meriska }\end{array}$ & Fair \\
\hline $\begin{array}{c}\text { 15. Wiratama } \\
\text { Sitorus }\end{array}$ & Good \\
\hline
\end{tabular}

Conclusion this assessment is obtained through the score table below:

\begin{tabular}{|c|c|}
\hline $\begin{array}{c}\text { Range } \\
\text { of final } \\
\text { scores }\end{array}$ & Categories \\
\hline $\begin{array}{c}86- \\
100\end{array}$ & Very good \\
\hline $71-85$ & Good \\
\hline $56-70$ & Fair \\
\hline $10-55$ & Poor \\
\hline
\end{tabular}

Based on the table category results above, fair is the most results. Therefore the results of this study are in the "fair" category.

In this research, the writer got the result that the verb error made by students is the mistake of using simple past tense, where the use of sentences that have been passed is used as a sentence that is happening.

In addition there are also errors in the use of simple present tense, which is the use of sentences that are being made into sentences that have passed. There are also verbs that are supposed to use the verb v2 but students write the verb $\mathrm{v} 1$.

For example:

Marketing $=$ verb of simple present

Marketed $=$ verb of simple past

Using $=$ verb of simple past

Used $=$ verb of simple present

Meet $=$ verb of $v 1$ 
Met $=$ verb of v2

In this study, found the causes of errors that occur in essayist verbs due to the lack of students understanding in determining the use of simple present tense or simple past tense, lack of vocabulary and lack of mastering grammar.

Therefore the most difficult part that discusses students in writing essays is determining the use of present tense and simple past tense tenses.

\section{RESULT AND DISCUSSION}

There are two previous researchers who have topics related to this research. First, Indrapasta's findings (2007: 71) find: errors (1) the most common are subjectwork agreement and the score is $28,25 \%$, (2) often find errors in verbs and meetings with 24, 66\% (3) spelling errors and are rated $17,94 \%,(4)$ The above score is $9.9 \%$, (5) word order sequences with a score of $8.07 \%$, (6) The errors needed are opposition voice sentences with a score of $4,93 \%,(7)$ articles (3.59\%), (8) prepositions (1.79\%), and pronouns and direct sentences with the same score, $0.45 \%$.

Second, the results of Sawalmeh (2013: 1) show that Arabic speakers in this study made ten common mistakes. These errors are: (1) verbs, (2) word order, (3) singular / plural forms, (4) agreement verbs, (5) double negatives, (6) spelling, (7) uppercase letters, (8) )) article (9) sentence Can be understood in previous writers, verbs are mistakes that are mostly still made by students in writing essays. Therefore, in this article the author chooses to find errors choosing essays on verbs only by finding it difficult to ask students to write essays.

And this third is the result of research by this author. The author gets the results of word errors in students' essay writing is "fair".

Based on data collection and discussion in the previous chapter the researchers stated the table above shows the ability of students to write essays that the category of "very good" was 1 student, "good" was 4 students, "fair" was 7 students and "poor" was 3 students.

So it can be concluded that the level of students' ability in writing English essays on verb errors is "fair".

The data taken by the author in this study were 15 students in eleventh grade of SMK Mulia Pratama, Medan.

In this study, found the causes of errors that occur in essayist verbs due to the lack of students understanding in determining the use of simple present tense or simple past tense, lack of vocabulary and lack of mastering grammar

Therefore the most difficult part faced by students in writing essays is to distinguish the use of simple present tense and simple past tense.

\section{REFERENCE}

Hasanah, Arifiatul. (2017). the Effects of Teaching Technique and Reading Habit towards

Students' Writing Skill at Junior High School in Serang. Journal of English Language Studies, 02(2), 141-154.

Khan, Shumaila Riaz and Mohammed Riaz, Khan. 2016. Error Analysis in English Writing.

International Multidisciplinary Research Journal. www.rersearch-chronicler.com ISSN2347-503X

Miles, M. B., Huberman, A. M., \& Saldana, J. (2014). Qualitative Data Analysis. Washington DC: SAGE Publications, Inc.

Nurhadi. (2019) Handbook of Writing. Jakarta : penerbit PT. Bumi Aksara. 
Bahasa Indonesia Prima, Vol 2, No. 1, 2020 e-ISSN: 2684-6780

Febriyanti,Rina Husnaini and Hanna Sundari. 2016. ERROR ANALYSIS OF ENGLISH WRITTEN ESSAY OF HIGHER EFL LEARNERS: A CASE STUDY. The Journal of English Language Studies Copyright@2016, p-ISSN: 2527-7022, e-ISSN: 25415131 Vol. 01, No. 02, September 2016, (71-80).

Sy, Sa'adiyah. 2019. A SYNTACTICAL ANALYSIS OF SIMPLE SENTENCES IN KEMBHANG
BABUR. Premise Journal, Vol. 8 No 2, and e-ISSN: 2442-482x, p-ISSN: 20893345, p.163-175. https://fkip.ummetro.ac.id/journal/inde x.php/english

Utama, Syatrya and Listianingsih. (2019) Panduan Praktis Menulis Artikel. Jakarta: Penerbit PRENADAMEDIA GROUP.

Widayoko, Agus. (2019) Menulis Artikel Ilmiah dan Esai. Bandung: Penerbit YRAMA WIDYA 